\title{
Effects of Clinical Mastitis on Reproductive Performance in Holstein Cows
}

\author{
A. GUNAY ${ }^{1}$, U. GUNAY ${ }^{2}$ \\ ${ }^{1}$ Vacational School of Technical Sciences, Uludag University, Gorukle, Bursa, Turkey \\ ${ }^{2}$ Department of Reproduction and Artificial Insemination, Faculty of Veterinary Medicine, Uludag University, \\ Gorukle, Bursa, Turkey \\ Received November 2, 2007 \\ Accepted June 11, 2008
}

\begin{abstract}
Gunay A., U. Gunay: Effects of Clinical Mastitis on Reproductive Performance in Holstein Cows. Acta Vet. Brno 2008, 77: 555-560.

The objective of this study was to determine the effects of clinical mastitis on reproductive performance in 135 early lactation cows. The animals were divided into two groups according to the occurrence of mastitis as follows: group I $(n=45)$, clinical mastitis prior to the first artificial insemination breeding; group II $(n=45)$, clinical mastitis after artificial insemination and being diagnosed pregnant. Forty-five cows without any mastitis served as control group.

Calving to first service intervals were significantly longer $(P<0.05)$ in cows with clinical mastitis before first service (group I; $95.2 \pm 5.4 \mathrm{~d}$ ) than in cows with clinical mastitis after first service (group II; $77.4 \pm 8.2 \mathrm{~d}$ ) and in control cows $(75.9 \pm 6.3 \mathrm{~d})$. Calving to conception interval with clinical mastitis before first service $(119.1 \pm 10.6 \mathrm{~d})$ and in cows with clinical mastitis after first service $(141.7 \pm 14.0 \mathrm{~d})$ was significantly longer $(P<0.05)$ than in control $(94.1 \pm 10.3 \mathrm{~d})$ cows. On the other hand, the number of services per conception was larger $(P<0.05)$ in cows with clinical mastitis after first service $(3.4 \pm 0.9)$ than in cows with clinical mastitis before first service $(2.1 \pm 0.9)$ and in cows with no clinical mastitis $(1.8 \pm 0.8)$. This study indicated that clinical mastitis during early lactation in Holstein cows had a negative impact on their reproductive performance.
\end{abstract}

Dairy cows, artificial insemination, fertility, service

Mastitis remains a disease causing the biggest economic losses to the dairy industry (Gill et al. 1990; Hortet and Seegers 1998; Pyorala 2002; Seegers et al. 2003). Mastitis comprises inflammation of the mammary gland, which is almost always linked with mastitis-causing organisms (O'Shea et al. 1984; Osteras and Lund 1988; Spencer 1988; Pyorala 2002). It is difficult to control because several different microbial species have the ability to infect the udder, especially during the post partum period. Pre-disposing factors are poor milking hygiene, milking machine faults, poor milking management, constitutional factors, teat injuries, teat sores and populations of pathogens on the cow's skin and epithelia and in its environment (Edmondson 2001; O'Shea et al. 1984; Osteras and Lund 1988; Sandholm et al. 1990; Woolford 1995; Pyorala 2002). Clinical symptoms include decreased milk production, increased numbers of leukocytes in milk, altered milk composition and appearance, increased body temperature, and red, warm and swollen mammary quarters (Fleischer et al. 2001; Hansen et al. 2004) and also lower reproductive performance (Cullor 1990; Moore et al.1991; Moore and O'Connor 1993; Barker et al. 1998; Huszenicza et al. 1998; Hockett et al. 2000; Schrick et al. 2001) in lactating cows. Pregnancy rates in dairy cattle have been decreasing over the last 30 years, and some authors (Royal et al. 2000; Stevenson 2001) claim that the pregnancy rate of 50-60\% in 1970's has declined to values of 35-50 today. Peter (2004) recorded that infectious diseases can cause anovulation, fertilization failure and embryonic mortality. Nevertheless, clinical mastitis causes decreased feed intake and alters metabolite concentrations, thus changing the hormonal profile of the cow and inhibiting follicular development (Oliver et al. 2000; Young 2000). Moore et al. (1991) indicated a negative correlation between

Address for correspondence:

Dr. Aytekin Gunay

Vacational School of Technical Sciences

Uludag University, 16059-Gorukle, Bursa

TURKEY
Phone: +90 2242942362

Fax: +90 2242942399

E-mail: agunay@uludag.edu.tr

http://www.vfu.cz/acta-vet/actavet.htm 
clinical mastitis and reproduction due to altered inter-oestrus interval and a shorter luteal phase in cows with clinical mastitis. Cullor (1990) reported that endotoxin, a component of the cell wall of gram-negative bacteria, induced luteolysis and influenced conception and early embryonic survival apparently via the release of inflammatory mediators.

The aim of this study was to determine the effect of clinical mastitis during the early post partum period on reproductive performance of Holstein dairy cows.

\section{Materials and Methods}

In this study 135 Holstein cows in lactation were gathered from 22 herds in the region of Bursa. The herds were kept on private family farms with milk production. All cows were milked two times daily. Average lactation number was $3.39 \pm 1.32$ (range $=1-7$ ). Animals calving healthy offspring and not having retained placenta at their last calving were chosen. Genital organs of all cows were examined by rectal palpation and vaginoscopy twice within 30 days after calving.

Oestrus signs were monitored by visual observation two times daily. The cows were inseminated at observed oestrus. Clinical mastitis was diagnosed by changes in the udder and milk compositions. Changes in the udder included pain, swelling, warmth and abnormal appearance of milk. Abnormal milk was detected using the strip cup test for the cow's udder quarters.

Milk samples from quarters of cows with clinical mastitis were collected aseptically. After collection the samples were examined microbiologically. Milk samples were streaked directly onto sheep blood agar and MacConkey agar plates for the isolation of bacteria. Plates were incubated at $37{ }^{\circ} \mathrm{C}$ in aerobic conditions and examined daily for 5 days for the presence of bacterial growth. The isolated bacteria were identified on the basis of cultural, morphological and biochemical characteristics (Konemann et al. 1992).

Nineteen lactating cows were divided into two groups according to the time of diagnosis of mastitis and 45 non-mastitis lactating cows constituted the control group.

Group I $(n=45)$ : had their first occurrence of clinical mastitis prior to the first artificial insemination

Group II $(n=45)$ : had their first occurrence of clinical mastitis between artificial insemination and pregnancy diagnosis

Control group $(n=45)$ : had no recorded occurrence of clinical mastitis during the first 90 days after calving.

Reproductive performance included calving to first service interval, calving to conception interval and the number of services per conception. Pregnancy was confirmed by rectal palpation 60-65 days after artificial insemination (AI). Data were analysed according to General Linear Model by ANOVA. Analyses were made using the statistical package of SPSS. A value of $P<0.05$ was considered significant.

\section{Results}

Pathogens isolated from the mammary glands are shown in Table 1 and the effects of clinical mastitis on reproductive performance are shown in Table 2.

Table 1. Mastitis pathogens isolated from mammary glands of Holstein cows with clinical mastitis during postpartum 90 days.

\begin{tabular}{|l|c|c|c|}
\hline Pathogen & Number of Cows & Group I $(\mathrm{n}=45)$ & Group II $(\mathrm{n}=45)$ \\
\hline Staphylococcus spp. & 38 & 13 & 25 \\
\hline Corynebacterium spp & 11 & 7 & 4 \\
\hline Escherichia coli & 9 & 3 & 6 \\
\hline Streptococcus spp. & 8 & 6 & 2 \\
\hline Yeast & 9 & 7 & - \\
\hline Enterobacter spp. & 3 & 3 & - \\
\hline Bacillus subtilis & 1 & 1 & 2 \\
\hline Mix pathogens & 7 & 5 & 4 \\
\hline Bacteriological negative & 4 & - & \\
\hline
\end{tabular}

When the effect of clinical mastitis on reproductive performance was examined, no significant differences were found for calving to first service interval between Group II $(77.4 \pm 8.2 \mathrm{~d})$ and the control $(75.9 \pm 6.3 \mathrm{~d})$. There were no significant differences in the number of services per conception between Group I $(2.1 \pm 0.9)$ and the control $(1.8 \pm$ $0.8)$. 
Table 2. The effect of clinical mastitis on reproductive performance

\begin{tabular}{|l|c|c|c|}
\hline \multicolumn{1}{|c|}{$\begin{array}{c}\text { Experimental } \\
\text { groups }\end{array}$} & $\begin{array}{c}\text { Calving to first service } \\
\text { interval }\end{array}$ & $\begin{array}{c}\text { Calving to } \\
\text { conception } \\
\text { interval }\end{array}$ & $\begin{array}{c}\text { Number of } \\
\text { services per } \\
\text { conception }\end{array}$ \\
\hline Group I $(\mathrm{n}=45)$ & $95.2 \pm 5.4^{\mathrm{b}}$ & $119.1 \pm 10.6^{\mathrm{b}}$ & $2.1 \pm 0.9^{\mathrm{a}}$ \\
\hline Group II $(\mathrm{n}=45)$ & $77.4 \pm 8.2^{\mathrm{a}}$ & $141.7 \pm 14.0^{\mathrm{c}}$ & $3.4 \pm 0.9^{\mathrm{b}}$ \\
\hline Control $(\mathrm{n}=45)$ & $75.9 \pm 6.3^{\mathrm{a}}$ & $94.1 \pm 10.3^{\mathrm{a}}$ & $1.8 \pm 0.8^{\mathrm{a}}$ \\
\hline
\end{tabular}

Data were presented as mean $\pm \mathrm{SD}$

a,b,c Different superscripts in the same column indicate significant differences $(P<0.05)$

On the other hand, there were significant differences $(P<0.05)$ for days open among all groups. All animals became pregnant in all experimental groups.

\section{Discussion}

There are several factors that have been shown to affect reproductive performance. These are not limited to the interval to first ovulation, the presence of a corpus luteum, circulating hormones, follicular growth, oestrus expression, ovarian diseases, early embryonic development and sperm and oocyte health (Kelton et al. 2001; Lucy 2001). However, mastitis has been shown to have a negative effect on reproduction in dairy cattle (Barker et al. 1998; Huszenicza et al. 1998; Oliver et al. 2000; Schrick et al. 2001; Santos et al. 2004; Huszenicza et al. 2005).

Previous studies (Cullor 1990; Moore and O'Connor 1993) reported that clinical mastitis caused by Gram-negative bacteria altered inter-oestrus intervals and increased the number of days to first service. Moore and O'Connor (1993) hypothesized that Gramnegative mastitis pathogens may stimulate the production of prostaglandin $\mathrm{F}_{2 \alpha}\left(\mathrm{PGF}_{2 \alpha}\right)$, which subsequently causes luteal regression, thus potentially causing the loss of an established pregnancy. But some authors (Barker et al. 1998; Kirk 2004) observed that Gram-positive and Gram-negative bacterial pathogens had similar effects on increasing the calving to first service interval, calving to conception interval and number of services per conception.

Schrick et al. (2001) reported that the calving to first service interval was significantly increased when clinical mastitis occurred before the first AI, compared to when it occurred after the first artificial insemination or in cows without clinical mastitis. Another study (Linderoth 2003) reported that cows that developed clinical or subclinical mastitis before their first service had increased calving to first service interval between 7 to 10 days, compared to uninfected herd mates. Our results were similar to Schrick et al. (2001) and Linderoth (2003) results.

Kirk (2004) found that cows that had clinical mastitis prior to their first breeding had an extended interval from calving to first AI. Cows that had mastitis prior to the diagnosis of pregnancy had decreased conception rates when compared to the controls.

In our study, the calving to first service interval with clinical mastitis before first service and with clinical mastitis after first service was longer than in control cows. The calving to conception interval was in agreement with results reported by Barker et al. (1998), Schrick et al. (2001), Linderoth (2003), Frago et al. (2004) and Kirk (2004). These researchers have confirmed that preventing mastitis in early lactation animals improves reproductive performance. Mastitis also affected the interval from calving to first service (Barker et al. 1998; Schrick et al. 2001). Barker et al. (1998) noted that cows that developed clinical mastitis after first service but before the establishment of pregnancy, had increased services per conception and days open (calving to conception interval). We found this result in accordance with Barker et al. (1998). Previous studies (Barker et al. 1998; Linderoth 2003) showed that clinical mastitis delayed oestrus; this result may have been 
due to decreased oestrogen levels and a lacking LH surge, resulting in the loss of oestrous behaviour. Hockett et al. (2000) pointed that this phenomenon could result from increased $\mathrm{PGF}_{2 \alpha}$ synthesis and subsequent luteal regression and (or) embryonic death. Mastitis leads to the production of bioactive molecules in the reproductive tract tissues. For example, $E$. coli endotoxin does not usually penetrate from the udder in to the blood, but can induce massive release of cytokines. These cytokine-mediated neural and endocrine changes play a key role in the inflammatory process (Huszenicza et al. 2005; Hansen et al. 2004).

The present study showed that the number of services per conception was longer for cows with clinical mastitis after the first service than for cows with clinical mastitis before first service and for cows with no clinical mastitis. These results were compounded by the fact that the number of services per conception increased from 1.8 for uninfected cows to 3.4 in cows with clinical mastitis after first service. Cows with clinical mastitis after first service typically had an increased number of services per conception compared to the control group. Schrick et al. (2001) and Frago et al. (2004) reported that the number of services per conception for clinical mastitis in early lactation cows was $2.1 \pm 0.2$ and $2.1 \pm$ 0.2 , respectively. Our findings were in agreement with the results reported by Schrick et al. (2001) and Frago et al. (2004).

On the other hand, Linderoth (2003) reported that the number of services per conception was 2.1 for cows with subclinical mastitis and 3.0 for cows with clinical mastitis compared to 1.6 for uninfected cows, and reported that most cows with clinical mastitis prior to the onset of oestrus did not show oestrus behaviour. In this study, the number of services per conception was found to be $2.1 \pm 0.9$, lower than 3.0 for cows with clinical mastitis reported by Linderoth (2003). Some researchers (Moore et al. 1991; Hansen et al. 2004; Peter 2004; Huszenicza et al. 2005) suggested that the increase in number of services per conception caused by mastitis is associated with anovulation at oestrus, fertilization failure and embryonic mortality. Young (2000) indicated that mastitis may have a negative influence on the establishment and/or maintenance of pregnancy through the hypothalamus-pituitary-ovarian axis, the uterine-ovarian axis or the nutritional effect on hormone levels.

In conclusion, the present study demonstrated that there was a relationship between mastitis and reproductive performance, and the occurrence of acute mastitis delayed the calving to first service interval, increased the calving to conception interval and elevated the number of services per conception. The results of this study showed that clinical mastitis has a detrimental effect on reproductive performance in early lactation cows.

\section{Vliv klinické mastitidy na reprodukční potenciál u Holštýnského skotu}

Cílem studie bylo zhodnotit vliv klinické mastitidy na reprodukční potenciál 135 krav v časném stádiu laktace. Sledovaná zvířata byla rozdělena do dvou skupin následujícím způsobem: skupina I $(n=45)$ obsahovala krávy s klinickou mastitidou před první umělou inseminací, skupina II $(n=45)$ zahrnovala zvírata, u nichž se klinická mastitida objevila po první umělé inseminaci a jež byla diagnostikována jako gravidní. Kontrolní skupinu tvořilo 45 zdravých zviŕat, u nichž se nevyskytoval žádný typ zánětu mléčné žlázy.

Inseminační interval byl ve skupině krav s př́iznaky klinické mastitidy před první inseminací (skupina I; $95.2 \pm 5.4$ d) statisticky významně delší $(P<0.05)$ než ve skupině zvířat s klinickou mastitidou po umělé inseminaci (skupina II; $77.4 \pm 8.2$ d) a v kontrolní skupině $(75.9 \pm 6.3$ d). Interval od otelení po další zabřeznutí u krav s klinickou mastitidou před první inseminací $(119.1 \pm 10.6$ d) a u skupiny zvířat s onemocněním po první inseminaci $(141.7 \pm 14.0 \mathrm{~d})$ byl významně delší $(P<0.05)$ než u zvířat v kontrolní skupině $(94.1$ $\pm 10.3 \mathrm{~d})$. Na druhou stranu počet inseminací do dalšího zabřeznutí byl vyšší $(P<0.05)$ u krav ze skupiny II s výskytem klinické mastitidy po první inseminaci $(3.4 \pm 0.9)$ než 
u zvířat ve skupině I $(2.1 \pm 0.9)$ a v kontrole $(1.8 \pm 0.8)$. Z této studie vyplývá, že klinická mastitida u Holštýnského skotu v časném stádiu laktace má negativní dopad na jejich reprodukční potenciál.

\section{Acknowledgement}

The authors wish to thank the Agricultural Office of the Yenișehir District for providing microbiological analyses results.

\section{References}

BARKER AR, SCHRICK FN, LEWIS MJ, DOWLEN HH, OLIVER SP 1998: Influence of clinical mastitis during early lactation on reproductive performance of Jersey cows. J Dairy Sci 81: 1285-1290

CULLOR JS 1990: Mastitis and its influence on reproductive performance in dairy cattle. Proceedings of International Symposium on Bovine Mastitis. Indianapolis, pp. 176-180

EDMONDSON P 2001: Influence of milking machines on mastitis. In Practice 23: 150-159

FLEISCHER P, METZNER M, BEYERBACH M, HOEDEMAKER M, KLEE W 2001: The relationship between milk yield and the incidence of some diseases in dairy cows. J Dairy Sci 84: 2025-2035

FRAGO F, AHMADZADEH A, SHAFII B, DALTON JC, MCGUIRE MA, PRICE WJ 2004: Effect of clinical mastitis and other diseases on reproductive performance of Holstein cows. J Dairy Sci 87 (Suppl): 258

GILL R, HOWARD WH, LESLIE KE, LISSEMORE K 1990: Economics of mastitis control. J Dairy Sci 73: 3340-3348

HANSEN PJ, SOTO P, NATZKE RP 2004: Mastitis and fertility in cattle - possible involvement of inflammation or immune activation in embryonic mortality. Am J Reprod Immunol 51: 294-301

HOCKETT ME, HOPKINS FM, LEWIS MJ, SAXTON AM, DOWLEN HH, OLIVER SP, SCHRICK FN 2000: Endocrine profiles of dairy cows following experimentally induced clinical mastitis during early lactation. Anim Reprod Sci 58: 241-251

HORTET P, SEEGERS H 1998: Loss in milk yield and related composition changes resulting from clinical mastitis in dairy cows. Prev Vet Med 37:1-20

HUSZENICZA G, JANOSI S, KULCSAR M, KORODI P, DIELEMAN SJ, BARTYIK J, RUDAS P, RIBICZEISZABO P 1998: Gram-negative mastitis in early lactation may interfere with ovarian and certain endocrine functions and metabolism in dairy cows. Reprod Domest Anim 33: 147-153

HUSZENICZA GY, JANOSI SZ, KUKSAR M, KORODI P, REICZIGEL J, KATAI L, PETERS AR DE, RENSIS F 2005: Effects of clinical mastitis on ovarian function in post-partum dairy cows. Reprod Domest Anim 40: 199-204

KELTON D, PETERSSON C, LESLIE, HANSEN, D 2001: Associations between clinical mastitis and pregnancy on Ontario dairy farms. Proceedings of the $2^{\text {nd }}$ International Symposium on Mastitis and Milk Quality. Canada, pp. 200-202

KIRK JH 2004: Effect of clinical mastitis on production and reproduction (E Suppl): E1-E2 (http://www.vetmed. ucdavis.edu/vetext/INF-DA/Mastitis-on-Produc.pdf), accessed December 7, 2006

KONEMANN EW, ALLEN SD, JANDA WM, SCHRECKENBERGER PC, WINN WC 1992: Color atlas and textbook of diagnostic microbiology, $4^{\text {th }}$ ed. J. B. Lippincott Philadelphia, 1154 p.

LINDEROTH S 2003: Don't let subclinical mastitis zap reproductive efficiency. Dairy herd management (http://www.dairyherd.com/printFriendly.asp?ed_id=2332), accessed December 15, 2006

LUCY MC 2001: ADSA foundation scholar award - reproductive loss in high-producing dairy cattle: Where will it end? J Dairy Sci 84: 1277-1293

MOORE DA, CULLOR JS, BONDURANT RH, SISCHO WM 1991: Preliminary field evidence for the Association of clinical mastitis with altered interestrus intervals in dairy-cattle. Theriogenology 36: 257-265

MOORE DA, O'CONNOR ML 1993: Coliform mastitis: its possible effects on reproduction in dairy cattle. Proc Natl Mastitis Counc, MO Natl Mastitis Counc, Kansas City, Arlington, pp. 162-166

OLIVER SP, SCHRICK FN, HOCKETT ME, DOWLEN HH 2000: Clinical and subclinical mastitis during early lactation impairs reproductive performance of dairy cows. Proceedings of National Mastitis Council, Inc. Regional Meeting (Cleveland, Ohio, 24 August, 2000), pp. 34-51

O'SHEA J, O'CALLAGHAN E, MEANEY WJ 1984: Effect of machine milking on new mastitis infections. Irish J Agric Res 23: 155-171

OSTERAS O, LUND A 1988: Epidemiological analyses of the associations between bovine udder health and milking machine and milking management. Prev Vet Med 6: 91-108

PETER AT 2004: An update on cystic ovarian degeneration in cattle. Reprod Domest Anim 39: 1-7

PYORALA S 2002: New strategies to prevent mastitis. Reprod Domest Anim 37: 211-216

ROYAL MD, DARWASH AO, FLINT APF, WEBB R, WOOLLIAMS JA, LAMMING GE 2000: Declining fertility in dairy cattle: changes in traditional and endocrine parameters of fertility. Anim Sci 70: 487-501

SANDHOLM M, KAARTINEN L, PYORALA S 1990: Bovine mastitis - why does antibiotic therapy not always work? An overview. J Vet Pharmacol Ther 13: 248-260

SANTOS JEP, CERRI RLA, BALLOU MA, HIGGINBOTHAM GE, KIRK JH 2004: Effect of timing of first clinical mastitis occurrence on lactational and reproductive performance of Holstein dairy cows. Anim Reprod Sci 80: $31-45$ 
SCHRICK FN, HOCKETT ME, SAXTON AM, LEWIS MJ, DOWLEN HH, OLIVER SP 2001: Influence of subclinical mastitis during early lactation on reproductive parameters. J Dairy Sci 84: 1407-1412

SEEGERS H, FOURICHON C, BEAUDEAU F 2003: Production effects related to mastitis and mastitis economics in dairy cattle herds. Vet Res 34: 475-491

SPENCER SB 1988: The milking machine as a cause of mastitis. Agri-Pract 9: 45-49

STEVENSON JS 2001: Reproductive management of dairy cows in high milk-producing herds. J Dairy Sci 84 (E Suppl): E128-E143

WOOLFORD MW 1995: Milking machine effects on mastitis progress $1985-1995$. In: Proceedings of the $3^{\text {th }}$ International Mastitis Seminar. Book II: p. section 7. Israel, pp. 3-12

YOUNG A 2000: Can mastitis have an effect on reproduction? Dairy management. November http://extension. usu.edu/files/agpubs/mastrepr.htm, accessed December 7, 2006 